\title{
A case study of agricultural residue availability and cost for a cellulosic ethanol conversion facility in the Henan province of China
}

\section{March 2012}

Prepared by

Erin G. Webb ${ }^{1}$

Yun $\mathbf{W u}^{2}$

${ }^{1}$ Environmental Sciences Division

${ }^{2}$ ORISE student programs






\section{DOCUMENT AVAILABILITY}

Reports produced after January 1, 1996, are generally available free via the U.S. Department of Energy (DOE) Information Bridge.

Web site http://www.osti.gov/bridge

Reports produced before January 1, 1996, may be purchased by members of the public from the following source.

National Technical Information Service
5285 Port Royal Road
Springfield, VA 22161
Telephone 703-605-6000 (1-800-553-6847)
TDD 703-487-4639
Fax 703-605-6900
E-mail info@ntis.gov
Web site http://www.ntis.gov/support/ordernowabout.htm

Reports are available to DOE employees, DOE contractors, Energy Technology Data Exchange (ETDE) representatives, and International Nuclear Information System (INIS) representatives from the following source.

Office of Scientific and Technical Information

P.O. Box 62

Oak Ridge, TN 37831

Telephone 865-576-8401

Fax 865-576-5728

E-mail reports@osti.gov

Web site http://www.osti.gov/contact.html

This report was prepared as an account of work sponsored by an agency of the United States Government. Neither the United States Government nor any agency thereof, nor any of their employees, makes any warranty, express or implied, or assumes any legal liability or responsibility for the accuracy, completeness, or usefulness of any information, apparatus, product, or process disclosed, or represents that its use would not infringe privately owned rights. Reference herein to any specific commercial product, process, or service by trade name, trademark, manufacturer, or otherwise, does not necessarily constitute or imply its endorsement, recommendation, or favoring by the United States Government or any agency thereof. The views and opinions of authors expressed herein do not necessarily state or reflect those of the United States Government or any agency thereof. 
Environmental Sciences Division

\title{
A CASE STUDY OF AGRICULTURAL RESIDUE AVAILABILITY AND COST FOR A CELLULOSIC ETHANOL CONVERSION FACILITY IN THE HENAN PROVINCE OF CHINA
}

Erin Webb and Yun Wu

Date Published: March 2012

\author{
Prepared by \\ OAK RIDGE NATIONAL LABORATORY \\ Oak Ridge, Tennessee 37831-6283 \\ managed by \\ UT-BATTELLE, LLC \\ for the \\ U.S. DEPARTMENT OF ENERGY \\ under contract DE-AC05-00OR22725
}





\section{CONTENTS}

Page

Contents. .iii

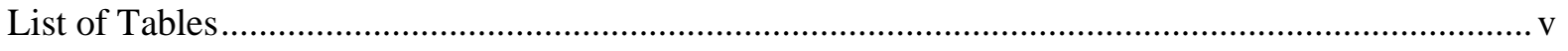

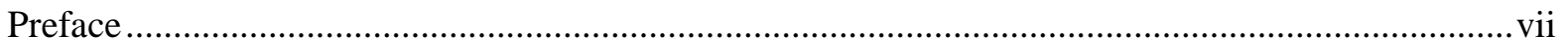

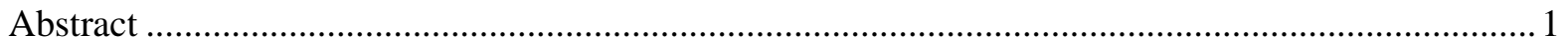

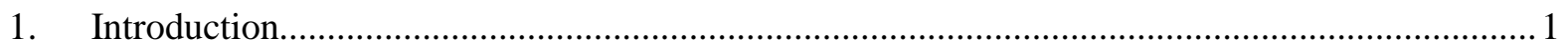

2. Methodology for Analysis of Agricultural Residue Availability and Cost ................................. 2

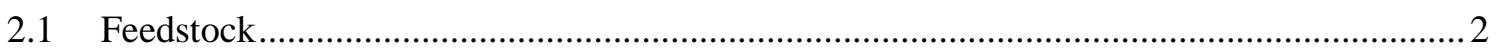

2.2 Feedstock Cost ............................................................................................... 2

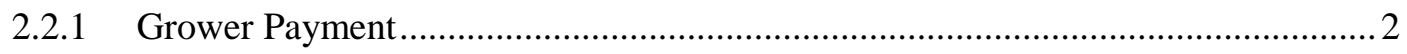

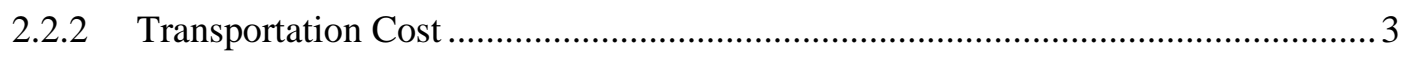

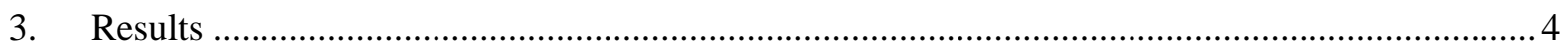

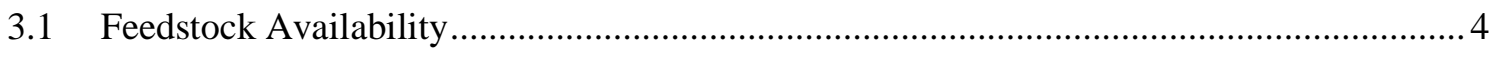

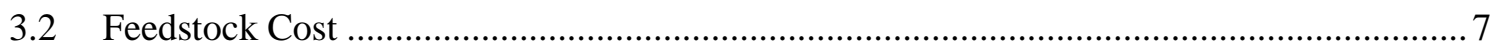



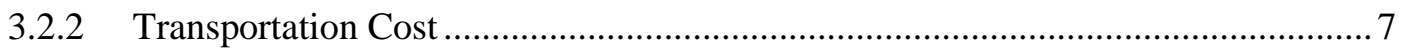

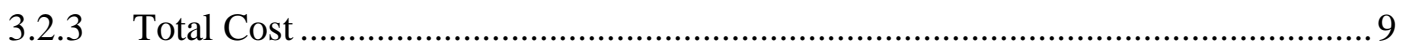

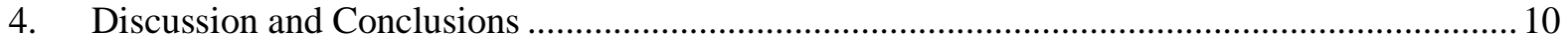



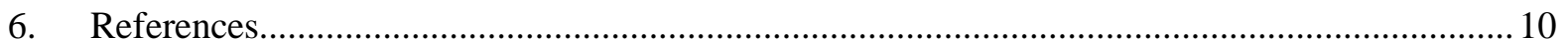





\section{LIST OF TABLES}

Table

Page

Table 1. Transportation data provided by Tianguan for their current system. ........................ 3

Table 2. Agricultural residue yields for regions within Nanyang City. Shaded columns

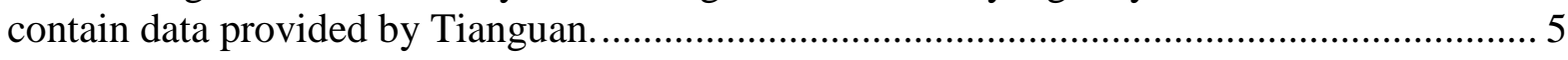

Table 3. Current residue utilization around the Tianguan biorefinery. For this analysis, it was assumed that only biomass currently considered waste is available for bioenergy................. 5

Table 4. Planting areas and residue availability for wheat straw and corn stover for a $20-\mathrm{km}$ (12-mile) radius surrounding biorefinery (data provided by Tianguan).............................. 6

Table 5. Feedstock supply design for a commercial U.S. corn stover to ethanol facility (Hess et al., 2009). 



\section{PREFACE}

This report was prepared as part of the China Biofuels Project funded by the U.S. Department of Energy. The purpose of this report was to use preliminary data on feedstock availability for a demonstration cellulosic ethanol facility in the Henan province of China to better understand units of measure and terminology used in China for bioenergy feedstock availability and cost analysis. The data was provided by the Henan Tianguan Enterprise Group identified by the China National Energy

Administration as part of a cooperative Memorandum of Understanding signed in 2008 between the NEA, the US Department of Energy, and the US Department of Agriculture. 



\begin{abstract}
A preliminary analysis of the availability and cost of corn stover and wheat straw for the area surrounding a demonstration biorefinery in the Henan Province of China was performed as a case study of potential cooperative analyses of bioenergy feedstocks between researchers and industry in the US and China. Though limited in scope, the purpose of this analysis is to provide insight into some of the issues and challenges of estimating feedstock availability in China and how this relates to analyses of feedstocks in the U.S. Completing this analysis also highlighted the importance of improving communication between U.S. researchers and Chinese collaborators. Understanding the units and terms used in the data provided by Tianguan proved to be a significant challenge. This was further complicated by language barriers between collaborators in the U.S. and China.
\end{abstract}

The Tianguan demonstration biorefinery has a current capacity of 3k tons (1 million gallons) of cellulosic ethanol per year with plans to scale up to 10k tons (3.34 million gallons) per year. Using data provided by Tianguan staff in summer of 2011, the costs and availability of corn stover and wheat straw were estimated. Currently, there are sufficient volumes of wheat straw and corn stover that are considered "waste" and would likely be available for bioenergy in the 20-km (12-mile) region surrounding the demonstration biorefinery at a low cost. However, as the industry grows, competition for feedstock will grow and prices are likely to rise as producers demand additional compensation to fully recover costs.

\title{
1. INTRODUCTION
}

The Henan Tianguan Enterprise Group (referred to hence as Tianguan) is one of four fuel companies designated by the Chinese national government to produce fuel ethanol (Tianguan website: http://www.tianguan.com.cn/english/about.asp). A Tianguan demonstration cellulosic ethanol biorefinery has been located in Nanyang City (Figure 1) of the Henan Province of Central China. It utilizes crop residues including corn stover and wheat straw as feedstocks to produce cellulosic ethanol. The capacity of the demonstration facility is 3k tons (1 million gallons) of cellulosic ethanol per year and plans are to scale up to produce 10k tons (3.34 million gallons) per year. Tianguan also plans to build a total of 15 biorefineries each with a capacity of 20k tons (6.68 million gallons) of cellulosic ethanol by year 2015 within the Henan province. The primary agricultural crops in and around Nanyang City are wheat and corn.

The objective of this case study was to perform a preliminary analysis of the availability and cost of corn stover and wheat straw for the Tianguan demonstration refinery. Though limited in scope, this analysis will provide insight into some of the issues and challenges of feedstock availability in China. Also, in comparing to U.S. cost and availability estimations, a better understanding of terms and units of measure used in evaluating biomass feedstocks in China versus the U.S. will be gained. Such understanding will be beneficial in subsequent analyses of bioenergy feedstocks in China. 


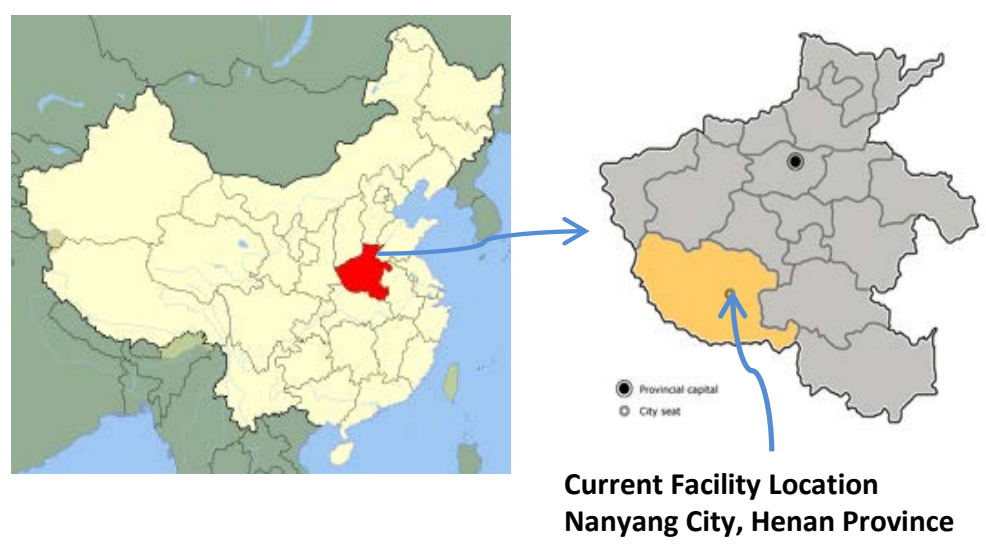

Figure 1. The focus of this feedstock case study analysis is the Tianguan Company demonstration biofinery in the Henan Province designed to produce 1 million gallons of cellulosic ethanol annually from corn stover and wheat straw. (Images from Wikipedia)

\section{METHODOLOGY FOR ANALYSIS OF AGRICULTURAL RESIDUE AVAILABILITY AND COST}

\subsection{FEEDSTOCK AVAILABILITY}

Estimates of corn stover and wheat straw availability were provided by Tianguan in summer 2011. As needed, units have been converted to be consistent with studies of feedstock availability in the U.S. for ease of comparison. The unit conversions used in this analysis are provided in section 5. Also, assumptions were made as needed to put the provided data into context. For example, in original data files provided by Tianguan, yields were labeled as "natural dry". We believe this refers to biomass that has been allowed to field dry and have assumed a moisture content of $18 \%$ (wet basis) for yield values provided by Tianguan and have converted to a dry basis accordingly. Unfortunately, given the challenges of differing languages it was not possible to confirm many of our assumptions. In future, more detailed analyses, the language barrier between U.S. researchers and the technical staff at partnering institutions in China must be addressed.

\subsection{FEEDSTOCK COST}

\subsubsection{Grower Payment}

For a case study such as this, the approach for estimating grower payment varies based on likely producer management decisions and available data. For example, in China, it is unclear what economic value is appropriate for the residues removed. It is hypothesized that farmers in this region of China do not value residues in the same way that U.S. producers do. Many Chinese farmers view the residues as a hindrance to subsequent planting operations and pursue methods of disposal such as burning despite laws prohibiting open burning in many areas. If this is the case, should grower payment account for the value of nutrient replacements as in the U.S. analysis? For this case study, an alternative of estimating grower payment as the value of nutrient removal was to use actual prices paid to farmers in the region surrounding the Tianguan facility (as reported by Tianguan in summer 2011). 


\subsubsection{Transportation Cost}

Farmers in the region surrounding the Tianguan plant have two options for delivering biomass to the biorefinery. They may deliver residues directly to the biorefinery or deliver to a field office owned by the company. The farmers' decision to deliver to the biorefinery or field office is based on their distance to the field office and biorefinery, available transportation options, quantity of biomass to be delivered and the biomass price. In this analysis, it is assumed that farmers choose the option that reduces the unit cost of delivered feedstock. Assuming each farmer has only one vehicle for transporting biomass, this most likely means delivery to the nearest drop-off location whether it is a field office or biorefinery. Individual farming operations in the region surrounding the Tianguan facility are small and tend to use tractors rather than large trucks for transporting biomass, as tractors are less expensive and can be used for multiple operations. Trucks are commonly used at the field offices to deliver biomass to the biorefinery. Currently, small tractors (shown in Figure 2) are used by more than $80 \%$ of all farmers delivering agricultural residues to the biorefinery. Table 1 shows biomass transportation data provided by Tianguan for their current system. These data were used to compare transportation costs to U.S. studies.

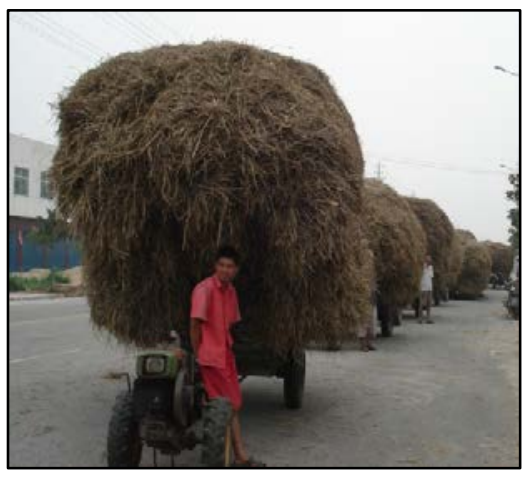

Figure 2. Small tractor used by majority of producers in China to deliver biomass to the biorefinery.

Table 1. Transportation data provided by Tianguan for their current system.

\begin{tabular}{|l|c|c|c|}
\hline & Small tractor (15-20 hp) & Large tractor & Truck \\
\hline Capacity, Mg/trip (ton/trip) & $1(1.1)$ & $3(3.3)$ & $9.5(10.5)$ \\
\hline Trips per day & 2 & 2 & 2 \\
\hline Fuel consumption, km/L (mi/gal) & $9.1(21.4)$ & $5(11.76)^{\mathrm{a}}$ & $2.86(6.72)$ \\
\hline Loading and unloading, yuan/day (\$/day) & $100(15.52)$ & $150(23.28)$ & $475(73.7)$ \\
\hline Diesel price, yuan/L (\$/gal) & \multicolumn{2}{|c|}{$6.30(\$ 3.71)$} \\
\hline
\end{tabular}

${ }^{\text {a }}$ Assumption based on reported fuel economy of small tractor and truck

Using the transportation data provided by Tianguan (Table 1), the variable and fixed costs of transporting biomass were calculated for the three primary vehicle types used in the Henan region. Either small or large tractors are used by most farmers to transport biomass a short distance to the local field office or to the biorefinery, if it is in close proximity to the farm. Larger capacity trucks are used to transport biomass from the field offices to the biorefinery. 
The portion of the variable cost attributed to fuel use was calculated as:

$$
C_{f u e l}=\frac{P_{\text {fuel }}}{F E * W}
$$

Where $\mathrm{C}_{\text {fuel }}=$ variable cost of fuel use, yuan/Mg-km

$\mathrm{P}_{\text {fuel }}=$ price of diesel fuel, yuan $/ \mathrm{L}$

$\mathrm{FE}=$ vehicle fuel economy, $\mathrm{km} / \mathrm{L}$

$\mathrm{W}=$ weight of biomass transported per load, $\mathrm{Mg}$

The price of fuel was assumed to be 6.55 yuan/L as reported by the World Bank (2012).

The variable cost of labor was calculated assuming that the biomass was transported $8 \mathrm{~km}(5 \mathrm{mi})$.

$$
C_{\text {labor }}=\frac{P_{\text {labor }}}{n * W_{\text {trip }} * D_{\text {trip }}}
$$

Where $\mathrm{C}_{\text {labor }}=$ variable cost of labor, yuan/Mg-km

$\mathrm{P}_{\text {labor }}=$ labor costs paid, yuan/day

$\mathrm{n}=$ number of trips, \#/day

$\mathrm{W}_{\text {trip }}=$ weight of biomass transported per load, $\mathrm{Mg}$

$\mathrm{D}_{\text {trip }}=$ distance of each trip, $\mathrm{km}$

The total variable cost is the sum of the labor and fuel costs. The fixed cost of loading and unloading biomass was calculated as:

$$
C_{\text {fixed }}=\frac{P_{\text {loading }}}{W_{\text {day }}}
$$

Where $\mathrm{C}_{\text {fixed }}=$ fixed costs that accounts for loading and unloading biomass, yuan/Mg

$\mathrm{P}_{\text {loading }}=$ cost of loading and unloading operations, yuan/day

$\mathrm{W}_{\text {day }}=$ weight of biomass transported daily, $\mathrm{Mg} / \mathrm{day}$

\section{RESULTS}

\subsection{FEEDSTOCK AVAILABILITY}

Estimates of planted areas and yields for wheat straw and corn stover in the Nanyang City region surrounding the Tianguan facility are shown in Table 2. Corn stover yields in China were lower than those observed in the U.S. It was expected that agricultural residue yields in China would be significantly less than in the U.S. However, data provided by Tianguan showed average corn stover yields of 6.76 dry Mg/ha. This was similar to stover yields in central Iowa of 5.33 and $6.96 \mathrm{Mg} / \mathrm{ha}$ for continuous corn and corn/soybean rotations, respectively, as reported by Karlen et al. (2011). 
Table 2. Agricultural residue yields for regions within Nanyang City. Shaded columns contain data provided by Tianguan.

\begin{tabular}{|c|c|c|c|}
\hline & $\begin{array}{l}\text { Yield }^{\mathrm{a}}, \\
\text { Mg/mu }\end{array}$ & $\begin{array}{c}\text { Yield, } \\
\text { dry } \mathrm{Mg} / \mathrm{mu}\end{array}$ & $\begin{array}{c}\text { Yield, } \\
\text { dry Mg/ha (dry tons/acre) }\end{array}$ \\
\hline Wheat straw & 0.28 & 0.23 & 3.38 (1.51) \\
\hline Corn stover & 0.55 & 0.45 & $6.76(3.02)$ \\
\hline
\end{tabular}

Compared to the U.S., where very little agricultural residues are currently utilized offsite (Kadam and McMillan 2003), Tianguan may have to compete with existing markets for corn stover and wheat straw. Table 3 shows estimates by Tianguan on current utilization of wheat straw and corn stover in the region surrounding the demonstration biorefinery in Nanyang City. It is expected that only $49 \%$ of wheat straw and $75 \%$ of corn stover may be available for bioenergy under current conditions. Therefore, given the acreages and yields in Table 2 and the fraction of residues available for bioenergy from Table 3, it is estimated that a total of $899.4 \mathrm{k}$ dry $\mathrm{Mg}$ (992.5k dry tons) of wheat straw and 948k dry Mg (1,046k dry tons) of corn stover are produced annually in the 20-km (12-mile) region surrounding the Nanyang City facility.

Table 3. Current residue utilization around the Tianguan biorefinery. For this analysis, it was assumed that only biomass currently considered waste is available for bioenergy.

\begin{tabular}{|l|c|c|c|c|c|}
\hline & Pulp & Feed & Handicrafts & Firewood & Waste \\
\hline Wheat Straw & $20 \%$ & $20 \%$ & $1 \%$ & $10 \%$ & $49 \%$ \\
\hline Corn Stover & & $20 \%$ & & $5 \%$ & $75 \%$ \\
\hline
\end{tabular}

Data for estimated planting area of corn stover and wheat straw by township were provided by Tianguan for the 20-km (12-mile) radius around the biorefinery (Table 4). Available wheat straw and corn stover were calculated assuming yields reported in Table 2 and availability estimates from Table 3. Again, for this analysis, it was assumed that only biomass currently considered waste is available for bioenergy. The planting area for wheat straw is $26 \%$ of total area within $20-\mathrm{km}$ circle. Planted area of corn is $15 \%$ of the total land area within a $20-\mathrm{km}$ circle.

Currently, the Tianguan company assumes a 10\% loss of biomass from the field to the biorefinery and a conversion rate of $1 \mathrm{Mg}$ ethanol per 7 dry Mg of biomass (43 gal/dry ton). Therefore, producing 10k Mg (3.34 million gallons) of cellulosic ethanol requires 70k dry Mg (77k dry tons) of crop residues delivered to the biorefinery. Considering the estimated 10\% biomass losses that occur during storage and transportation, the total harvested feedstock should be 77k dry Mg (85k dry tons). From Table 4, the estimated available supplies of residue are approximately 60k dry Mg (66k dry tons) of wheat straw and 98k dry Mg (108k dry tons) of stover. Assuming that the biorefinery can utilize wheat straw and stover in their conversion process, there is sufficient biomass within the $20-\mathrm{km}$ (12-mile) radius around the biorefinery. 
Table 4. Planting areas and residue availability for wheat straw and corn stover for a 20-km (12-mile) radius surrounding biorefinery (data provided by Tianguan).

\begin{tabular}{|c|c|c|c|c|c|c|}
\hline Township & $\begin{array}{l}\text { Wheat } \\
\text { planting } \\
\text { area, mu }\end{array}$ & $\begin{array}{l}\text { Wheat planting } \\
\text { area, ha (acres) }\end{array}$ & $\begin{array}{c}\text { Available }^{\mathrm{a}} \\
\text { wheat straw, } \\
\text { dry Mg } \\
\text { (dry tons) }\end{array}$ & $\begin{array}{c}\text { Corn } \\
\text { planting } \\
\text { area, } \\
\text { mu } \\
\end{array}$ & $\begin{array}{l}\text { Corn planting } \\
\text { area, ha (acres) }\end{array}$ & $\begin{array}{c}\text { Available }^{\mathrm{b}} \text { corn } \\
\text { stover, } \\
\text { dry Mg } \\
\text { (dry tons) } \\
\end{array}$ \\
\hline 1 & 1,600 & $110(300)$ & $190(210)$ & 800 & $50(100)$ & $300(330)$ \\
\hline 2 & 16,000 & $1,100(2,600)$ & $1,900(2,100)$ & 7,000 & $500(1,200)$ & $2,500(2,800)$ \\
\hline 3 & 31,000 & $2,100(5,100)$ & $3,800(4,200)$ & 15,000 & $1,000(2,500)$ & $5,100(5,600)$ \\
\hline 4 & 35,000 & $2,300(5,800)$ & $4,300(4,700)$ & 25,000 & $1,700(4,100)$ & $8,600(9,500)$ \\
\hline 5 & 39,000 & $2,600(6,400)$ & $4,700(5,200)$ & 41,000 & $2,700(6,800)$ & $13,700(15,100)$ \\
\hline 6 & 57,000 & $3,800(9,400)$ & $6,900(7,600)$ & 34,000 & $2,300(5,600)$ & $11,700(12,900)$ \\
\hline 7 & 29,000 & $1,900(4,800)$ & $3,500(3,900)$ & 15,000 & $1,000(2,500)$ & $5,100(5,600)$ \\
\hline 8 & 42,000 & $2,800(6,900)$ & $5,100(5,600)$ & 35,000 & $2,300(5,600)$ & $11,700(12,900)$ \\
\hline 9 & 37,000 & $2,500(6,100)$ & $4,500(5,000)$ & 21,000 & $1,400(3,500)$ & $7,100(7,800)$ \\
\hline 10 & 24,500 & $1,600(4,000)$ & $3,000(3,300)$ & 17,000 & $1,100(2,800)$ & $5,600(6,200)$ \\
\hline 11 & 59,000 & $3,900(9,700)$ & $7,200(7,900)$ & 25,200 & $1,700(4,200)$ & $8,600(9,500)$ \\
\hline 12 & 54,000 & $3,600(8,900)$ & $6,600(7,300)$ & 24,700 & $1,600(4,100)$ & $8,100(8,900)$ \\
\hline 13 & 59,700 & $4,000(9,900)$ & $7,300(8,000)$ & 25,000 & $1,700(4,100)$ & $8,600(9,500)$ \\
\hline 14 & 13,000 & $900(2,100)$ & $1,600(1,800)$ & 5,000 & $300(800)$ & $1,500(1,700)$ \\
\hline Total & 497,800 & $33,000(82,000)$ & $60,600(66,800)$ & 290,700 & $19,400(47,900)$ & $98,200(108,330)$ \\
\hline
\end{tabular}

Tianguan's future plans call for the construction of 15 biorefineries, each with a capacity of 20k tons (6.68 million gallons) of ethanol in the Henan Province by the year 2015. For current conversion rate estimates, this will require 154k dry Mg (170k dry tons) of biomass per facility per year. Assuming that the 20-km (12-mile) radius surrounding the current demonstration biorefinery is typical of conditions throughout the Henan Province, additional residues, or other feedstocks, beyond that which is currently considered "waste" (Table 3) will be needed. Potential solutions include higher prices paid for agricultural residues to increase competition with current uses, expanding corn and wheat production, and/or exploring additional feedstocks.

If, however, research and development efforts at the demonstration-scale biorefinery improve conversion rates, less feedstock will be required. For example, improving the conversion rate by 25\% to $1 \mathrm{Mg}$ ethanol per 5.6 dry $\mathrm{Mg}$ of biomass (54 gal/dry ton), will reduce the feedstock required for a $20 \mathrm{k} \mathrm{Mg}$ ethanol facility from 154k dry Mg (169.7k dry tons) of biomass to $123.2 \mathrm{k}$ dry Mg (135.8k dry tons) of biomass per year. Clearly, improvements in the conversion rate of biomass to fuel will be beneficial to the success of these facilities.

For comparison, data for a feedstock supply system proposed by Hess et al (2009) for a cellulosic ethanol facility in the Midwest U.S. utilizing corn stover is shown in Table 5. The U.S. design is a supply chain capable of delivering 800k dry tons of biomass per year to a commercial biorefinery. Assuming an ethanol yield of 80 gal/dry ton (U.S. Department of Energy 2011), this biorefinery is expected to produce 64 million gallons of ethanol annually. If Tianguan expanded to build a commercial-size biorefinery capable of producing 64 million 
gallons (191.6k Mg ethanol) of ethanol annually like those envisioned for the U.S., the required feedstock supply would be nearly 1.2 million dry Mg of biomass. Given the yields and the fraction of stover available for bioenergy from Table 2 and Table 3, an assumption that 26\% of area is planted in wheat and $15 \%$ in corn (per estimates above), and assuming homogeneous distribution of feedstock, supplying a biorefinery of this size would require a draw radius of 93 $\mathrm{km}(58 \mathrm{mi})$ for wheat straw or $69 \mathrm{~km}(43 \mathrm{mi})$ for corn stover. The land area required for a facility using stover is less than that for a biorefinery using wheat straw due to higher yields and assumption that more stover is currently considered waste (75\% versus $49 \%$ for wheat straw).

Table 5. Feedstock supply design for a commercial US corn stover to ethanol facility (Hess et al., 2009).

\begin{tabular}{|l|l|}
\hline Plant operation size (delivered feedstock) & 725,953 dry Mg/year (800,000 dry ton/year) \\
\hline Feedstock harvested annually & 780,339 dry Mg $(860,000$ dry ton $)$ \\
\hline Cultivated area & 853,000 ha $(2,107,000$ acres $)$ \\
\hline Area available for contract & 426,500 ha $(1,054,000$ acres $)$ \\
\hline Participating acres & $50 \%$ \\
\hline Corn acres harvested annually & 213,300 ha $(527,000$ acres $)$ \\
\hline Feedstock draw radius & $72.9 \mathrm{~km}$ (45.3 miles) \\
\hline
\end{tabular}

\subsection{FEEDSTOCK COST}

\subsubsection{Grower Payment}

Since there is currently no national market for crop residues as bioenergy feedstocks in the U.S., the delivered cost of these feedstocks at the biorefinery is estimated as the sum of the grower payment and the logistic costs (Hess et al., 2009). Grower payment is the compensation a producer receives for supplying biomass and the minimum grower payment is the price at which a producer can recover the direct and indirect costs related to biomass removal. In the case of agricultural residues, the cost to produce the crop is attributed to the grain cost so the production costs of corn stover and wheat straw are zero. Instead the value of the nutrients removed plus some grower profit is accounted for in the grower payment. Recognizing that crop residues are a nutrient source if left to decompose on fields, the value of nutrients removed is estimated as the cost of fertilizers that will be needed to replace these nutrients. For 2006-2008 the average grower payment for stover in the U.S., including a profit of $\$ 2.00-2.50 /$ dry ton varying with region, was \$15.90/DM ton (Hess, et al 2009).

Based on the data provided by Tianguan, it was not possible to determine the portion of the delivered cost that was the grower payment. In future work, estimates of collection and storage costs of feedstocks in China are needed to isolate the grower payment. Estimates of grower payments will be useful as Tianguan and other companies plan and build biorefineries. As agricultural residues as a feedstock for bioenergy begins to compete with other uses for biomass, the grower payment will have a significant impact on the availability of bioenergy feedstocks.

\subsubsection{Transportation Cost}

Table 6 shows the results of transportation cost calculations obtained using the method described in section 2.2.2. 
Table 6. Transportation cost estimates.

\begin{tabular}{|l|c|c|c|}
\hline & Small tractor $(\mathbf{1 5 - 2 0} \mathbf{h p )}$ & Large tractor & Truck \\
\hline Fuel cost, yuan/Mg-km (\$/ton-mile) & $0.72(\$ 0.17)$ & $0.44(\$ 0.10)$ & $0.24(\$ 0.06)$ \\
\hline Labor cost, yuan/Mg-km (\$/ton-mile) & $4.69(\$ 1.08)$ & $1.56(\$ 0.36)$ & $0.49(\$ 0.11)$ \\
\hline Variable cost, yuan/Mg-km (\$/ton-mile) & $5.41(\$ 1.25)$ & $2.00(\$ 0.46)$ & $0.73(\$ 0.17)$ \\
\hline Fixed cost, yuan/Mg (\$/ton) & $50(\$ 7.20)$ & $25(\$ 3.60)$ & $25(\$ 3.60)$ \\
\hline
\end{tabular}

The unit costs of transporting biomass using the three available options are:

$$
\begin{array}{ll}
\text { Small tractor: } & C=5.41 * D+50 \\
\text { Large tractor: } & C=2.00 * D+25 \\
\text { Truck: } & C=0.73 * D+25
\end{array}
$$

Where $\mathrm{C}=$ unit cost to transport biomass, yuan $/ \mathrm{Mg}$

$\mathrm{D}=$ distance to biorefinery, $\mathrm{km}$

In standard U.S. units, these costs are:

$$
\begin{array}{ll}
\text { Small tractor: } & C=\$ 1.25 * D+\$ 7.20 \\
\text { Large tractor: } & C=\$ 0.46 * D+\$ 3.60 \\
\text { Truck: } & C=\$ 0.17 * D+\$ 3.60
\end{array}
$$

Where $\mathrm{C}=$ unit cost to transport biomass, $\$$ ton

$\mathrm{D}=$ distance to biorefinery, $\mathrm{mi}$

Searcy et al. (2007) estimated costs of transporting biomass by truck and by rail in the U.S.. For stover and wheat straw the variable and fixed costs adjusted to 2010 dollars are \$0.12/ton-mile and $\$ 4.47 /$ ton, respectively. Compared to the China scenario, variable costs for trucking biomass are slightly lower in the U.S. (\$0.17/ton-mile for China case presented here versus \$0.12/tonmile for the U.S. as calculated by Searcy et al.). Fixed costs of loading and unloading are approximately $24 \%$ higher for the U.S. case. As an example for comparison, the cost to transport biomass 10 miles would be approximately \$5.30/ton for the Tianguan scenario and \$5.69/ton for average U.S. conditions. Figure 3 shows the sensitivity of transportation cost (\$/ton) to distance for the three vehicle types used in the Tianguan scenario compared with the U.S. trucking costs estimates for stover and straw (Searcy et al, 2007). As expected, the small tractor is the least cost effective. Tractors are most suitable for short in-field hauls. Utilizing trucks for transporting biomass from the farm to the field office or biorefinery could significantly reduce supply chain costs. Possible options for making trucks available to transport biomass from the farm include contract hauling, farmers pooling resources to gain access to a truck, or the biorefinery company picking up biomass from the farm. 
Figure 3. Transportation cost as a function of distance for the small tractor, large tractor, and truck of the Tianguan scenario and for a U.S. truck based on Searcy et al. (2007).

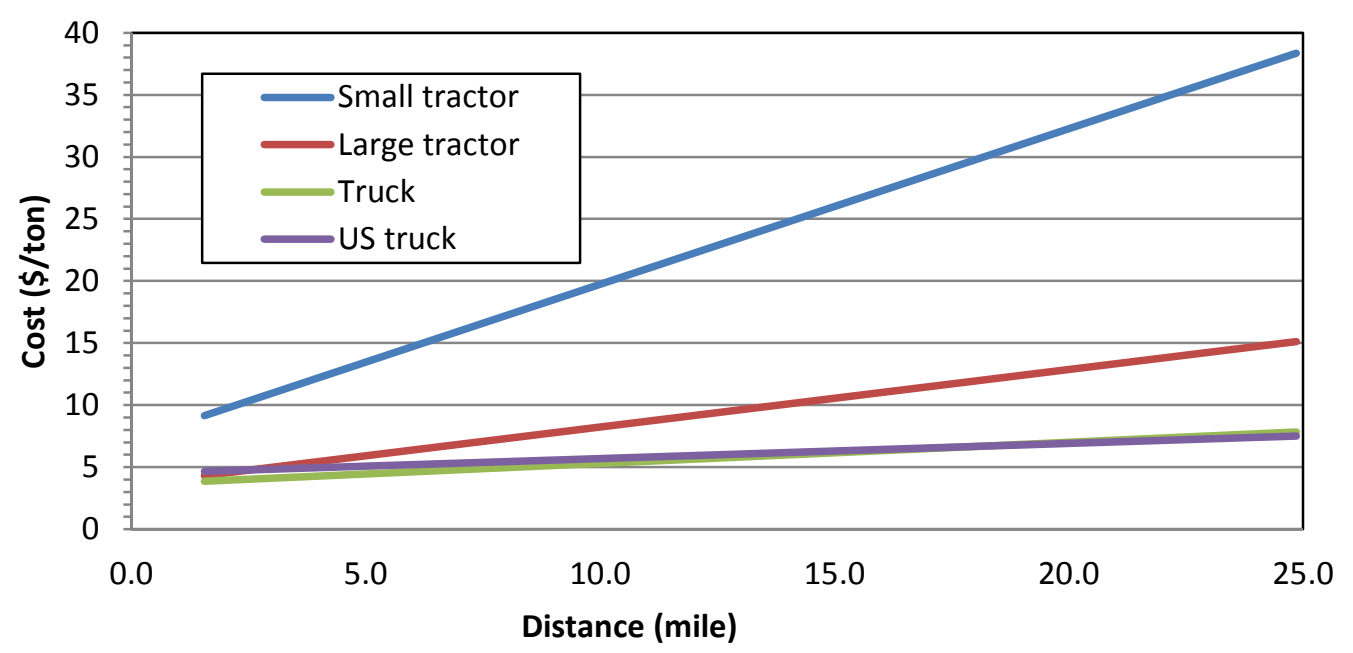

\subsubsection{Total Cost}

Delivered prices reported by Tianguan and reported by Hess et al. (2009) are shown in Table 7. The calculated transportation cost of \$18/dry ton for the China case was calculated assuming that biomass is transported two miles by large tractor plus 10 miles by truck using the relationships developed in section 3.2.2. For more detailed analyses, better estimates of transportation cost are needed.

Table 7. Comparison of delivered prices of corn stover for bioenergy in the U.S. and China. Feedstock costs for Tianguan were provided by the company and cost estimates for the U.S. were taken from Hess et al. (2009)

\begin{tabular}{|l|c|c|c|c|c|}
\hline & $\begin{array}{c}\text { Grower } \\
\text { payment }\end{array}$ & Collection & Storage & $\begin{array}{c}\text { Handling \& } \\
\text { Transportation }\end{array}$ & $\begin{array}{c}\text { Delivered } \\
\text { price }\end{array}$ \\
\hline U.S. (\$/dry ton) & $\$ 15.90$ & $\$ 21.61$ & $\$ 8.11$ & $\$ 11.94$ & $\$ 57.6$ \\
\hline Tianguan (\$/dry ton) & $\begin{array}{c}\text { Data not } \\
\text { available }\end{array}$ & $\begin{array}{c}\text { Data not } \\
\text { available }\end{array}$ & $\begin{array}{c}\text { Data not } \\
\text { available }\end{array}$ & $\$ 18$ & $\$ 37$ \\
\hline
\end{tabular}

Though it is expected that transportation costs in China will exceed those in the U.S. due to the lack of equipment suited for transporting biomass, the delivered cost of feedstock in China was over 35\% less than estimates for the U.S. Additional analyses are needed to better understand the cost components of the China data and to validate the U.S. cost estimates. It is speculated that producers in China were not fully compensated for the value of nutrients removed as they would be in the U.S. scenario presented by Hess et al. (2009). Although producers in China might perceive crop residue values differently, as the demand for residues goes up they are likely to attach much higher value to the residues causing prices to increase. This will become increasingly important as the demand for feedstocks increases. The grower payment alone is not enough to explain the differences between the delivered prices of feedstocks in the U.S. and China. Some possible explanations for this discrepancy include: producers were not fully compensated for their costs, or perhaps more likely, the data provided by Tianguan was not interpreted correctly. This again points to the importance of communication between U.S. researchers and China partners in completing joint feedstock analyses. 


\section{DISCUSSION AND CONCLUSIONS}

Several lessons were learned in the study presented here to evaluate the availability and cost of wheat straw and corn stover for a demonstration cellulosic ethanol facility in the Henan Province of China. Data provided in the summer of 2011 by Tianguan was analyzed and compared to expected scenarios for agricultural residue supply systems for bioenergy facilities in the U.S. Currently, there are sufficient volumes of wheat straw and corn stover that are considered "waste" and would likely available for bioenergy in the 20-km (12-mile) region surrounding the demonstration biorefinery at a low cost (\$37/dry ton compared to an expected $\$ 57 /$ dry ton in the U.S.). However, as the industry grows, competition for feedstock will grow and prices are likely to rise as producers demand additional compensation to fully recover costs. In particular, it is speculated that Chinese producers were not provided a grower payment that covers the value of nutrients removed when wheat straw and corn stover are collected as they would be in the U.S. Lack of value placed on nutrients removed in residue collection likely affects producer decisions regarding the collection and sale of agricultural residues. It would be interesting to better explore this producer attitude and how it affects environmental sustainability (i.e., soil carbon) of the operation. Other ways identified in this study to improve the economics of cellulosic ethanol production were to improve ethanol conversion rates and reduce logistics costs.

It is also recognized that better efforts to improve communication between U.S. researchers and Chinese collaborators is needed to improve analyses such as this. Understanding the units and terms used in the data provided by Tianguan proved to be a significant challenge in completing this analysis. This was further complicated by language barriers between collaborators in the U.S. and China.

\section{UNIT CONVERSIONS}

\begin{tabular}{|l|l|l|}
\hline Multiply & by & To obtain \\
\hline $\mathrm{mu}$ & 0.165 & acres \\
\hline $\mathrm{mu}$ & 0.0667 & hectares (ha) \\
\hline metric tonne ethanol & 334 & gallons (gal) \\
\hline yuan & 0.1552 & dollars (\$) \\
\hline yuan per liter (yuan/L) & 0.587 & dollars per gallon (\$/gal) \\
\hline
\end{tabular}

\section{REFERENCES}

Hess, J. R., K. L. Kenney, C. T. Wright, R. Perlack, and A. Turhollow. 2009. Corn stover availability for biomass conversion: situation analysis. Cellulose 16 (4):599-619.

Kadam, K. L., and J. D. McMillan. 2003. Availability of corn stover as a sustainable feedstock for bioethanol production. Bioresource Technology 88 (1):17-25.

Karlen, D. L., S. J. Birell, and J. R. Hess. 2011. A five-year assessment of corn stover harvest in central Iowa, USA. Soil \& Tillage Research 115:47-55.

Searcy, E, P Flynn, E Ghafoori, and A Kumar. 2007. The Relative Cost of Biomass Energy Transport. Applied Biochemistry and Biotechnology 137-140:639-652.

The World Bank. 2012. Pump Price for Diesel Fuel 2012 [cited February 27 2012]. Available from http://data.worldbank.org/indicator/EP.PMP.DESL.CD.

U.S. Department of Energy. 2011. Biomass Multi-Year Program Plan. Washington, DC: U.S. Department of Energy. 